\title{
Ways to Training of Teachers' Comprehensive Quality in Normal Colleges and Universities
}

\author{
Yanxia Wang \\ Department of Foreign Language Teaching \\ Tonghua Normal University \\ Tonghua, China
}

\begin{abstract}
Education is a fundamental task and it is crucial for generations. In the background of knowledge economy, more and more people want to enter the institution of higher education for further study. Colleges and universities in China is increasing in number and expanding in scale. Under this background, it is an urgent problem to ensure and improve the quality of higher education in the various institutions. The quality of teachers is one of the key factors to improve the schooling quality of universities and colleges. Therefore, the paper started from the present situations of normal colleges and universities in Jilin, and discussed the ways to train the comprehensive quality of teachers in colleges and universities, so as to ensure the quality of teaching in colleges and universities.
\end{abstract}

Keywords-normal colleges and universities; teachers; comprehensive quality; training; ways

\section{INTRODUCTION}

Today's competition is focused on talents, and teachers are the key to talent training. It can be said that the comprehensive quality of teachers directly determines the level of teaching in normal colleges and universities. It is important to understand the quality of teachers in colleges and universities of our country, be aware of the shortcomings in teaching and make improvements for improving the comprehensive quality of teachers and the teaching level of colleges and universities in colleges and universities in China. Therefore, it is urgent for our country's higher education reform to understand the comprehensive business quality and ability of teachers in normal colleges and universities through effective survey and

Fund project: the project of the teaching guidance committees of foreign languages in occupation colleges and universities affiliated to the Ministry of Education: Teachers' Development on English Course Construction in Higher Vocational Colleges (GZWYJXGG-018); the project of social science in Jilin Province: Research of Countermeasures for Training and Improving the Comprehensive Quality of Teachers in Jilin Normal Universities and Colleges (2016B343); the annual topic of 2017's 13th Five-Year Plan of Education Science of Jilin Province: Teachers' Professional Development Research Guided by the Optimization of College English Curriculum (GH170531); the research topic on higher education and teaching reform in Tonghua Normal University: Teachers' Professional Development Research based on Students' Demand Analysis for College English Curriculum (JY2016052); the annual topic of 2016's 13th Five-Year Plan of Education Science of Jilin Province: Study of English Teachers of Local Universities required by Education Informationization (GH16345); the annual topic of 2017's 13th Five-Year Plan of Education Science of Jilin Province: Study on the Situation and Motivation of Teachers' Loss in Primary and Middle Schools in the Mountainous Southeast Jilin Province (ZD17112); carry out effective teacher training activities.

\section{THE PROBLEMS EXISTING IN THE COMPREHENSIVE QUALITY OF TEACHERS IN NORMAL COLLEGES AND UNIVERSITIES}

Before the study of this topic, the author took teachers in normal colleges and universities in Jilin Province as the research object and knew their moral quality, professional knowledge, professional skills and other aspects, analyzed the factors influencing the training and improvement of comprehensive quality of teachers in normal colleges and universities and put forward corresponding suggestions. The following problems are found in this questionnaire survey:

\section{A. Weak Faculty Force}

According to the survey, most teachers in normal universities and colleges in Jilin have engaged in front-line teaching work or served as a research member. They have rich teaching experience, but not high educational background, so they have limited professional knowledge. It limits the improvement of their comprehensive quality. In addition, some teachers in normal colleges and universities have higher education and solid theoretical knowledge. Generally, schools take these teachers seriously, so they are entrusted in an important post after work in school. They directly take charge of teaching work. Compared with teachers with lower diploma, they lack training opportunities at the grassroots level. It is easy for them to be ambitious and cease to advance. Teachers with lower diploma but rich experience and teachers with higher diploma but lacking experience form an imbalance, which makes faculty force of normal colleges and universities in Jilin weak. It greatly influences the improvement of teaching effect in higher education. If we want to improve the comprehensive quality of teachers and ensure teaching level, we need to enhance the faculty force and change the unmatched situation of teacher's diploma and teaching experience.

\section{B. Backward Teaching Ideas}

According to the questionnaire, the teaching ideas of teachers are relatively backward, especially in remote normal colleges and universities. Teachers in these areas neglects student's subject position, and emphasize the theory rather than practice in teaching. In classroom teaching, teachers only 
pay attention to the transmission of knowledge and pay no attention to the reception of the students. In class design they don't know how to arouse students' participation and know the students' mastery of knowledge. In addition, in the course of development, teachers attach great importance to the theoretical guidance of students. They thought that one mastering the theoretical knowledge can understand the actual usage. It results that the students' practical ability is inferior to their theoretical level. But the practice ability is an important quality normal students should have. Therefore, it is necessary for teachers in Jilin to change their backward teaching ideas in order to improve the teaching level of normal colleges and universities in Jilin. Advanced teaching ideas can improve the teaching level.

\section{Paying Little Attention to the Training of Teachers' Comprehensive Quality}

It needs teachers' self effort and school's help to improve their comprehensive quality. According to the results of the questionnaire, most of teachers have participated in trainings arranged by school. But the training effect is not obvious. Even some training is only superficial. In addition, some teachers said schools are not serious about teaching arrangement unless the departments of education issue an inspection notice. For example, some of the schools don't check the final examination papers strictly and approve them when they think the number of examination questions is enough. They don't consider the degree of difficulty of the paper. Under the premise, teachers may be go-slow in designing the paper. Some teachers even use the final examination paper of last year. Schools pay little attention to the teaching quality evaluation. It is an improve reason leading to a low comprehensive quality of normal colleges and universities. If we want to change this situation, schools need to enhance teachers' comprehensive quality and inspection and review on teacher's teaching quality.

\section{THE NEW REQUIREMENTS OF THE SOCIETY FOR TEACHERS IN THE NEW ERA}

Now our higher education is transferring from elite education to mass education. The number of colleges and universities is increasingly increased and the scale is expanding, which also brings a lot of problems in its development. And we shall solve them urgently. Normal colleges and universities are an important part of higher education in our country. They undertake the task of training teachers of all kinds. Therefore, it is particularly important to improve the comprehensive quality of teachers in normal colleges and universities. But in the new era, except for diploma degree and teaching experience, we have new requirements and goals for teachers:

\section{A. Think Hard}

In the new era, society requires teachers to think hard. Each person's life is not perfect. No one is perfect. It is meaningless to sigh after the happening of bad things. We should learn to think and find our shortcomings, so as our guider teacher. Only by thinking hard can teachers face their shortcomings in their teaching and life, and can they summarize the teaching experience objectively, reflect their work and life and make progress continually. Thus, improve their comprehensive quality.

\section{B. Dare to Explore}

Under the new era, teachers should dare to explore. In today's era of big data, the update speed of knowledge is quick. Teachers need to continue to study, continue to explore, and gradually adapt to the demands of economic and social development in the exploration. At same time, improve their level of knowledge and comprehensive quality constantly. It requires teachers to ask questions if they have problems or doubts in work and life and to obtain the answers through continuous exploration. Thus, they can develop the spirit of exploration while mastering one skill. Therefore, it is an important requirement of the new era for teachers to dare to explore. Teachers should dare to explore in order to improve their comprehensive quality.

\section{Self-perfect}

Under the new era, teachers should constantly improve themselves and continue to pursue with speaker's eloquence, host's demeanor, actor's deportment, general's spirit, rather than be serious in speech and manner with a stiff face behind a pair of black-rimmed glasses. To realize the transformation of the image, teachers should have their own pursuit and enjoy their work, life and study. Through the unremitting efforts, they can create a perfect image, and develop their comprehensive quality. Therefore, under the background of the new era, teachers need to have their own pursuit and do their best in order to improve their comprehensive quality.

\section{Have a Good Professional Ethic}

A good professional ethic is also one of the important qualities that teachers need to have in the new age. One teacher does not have a good professional ethic is not welcomed by students. And his/her teaching efficiency and level cannot be improved. On the contrary, if a teacher has a good professional ethnic, his/her class will be welcomed by students. In the information and network era, students can quickly get knowledge they want through network. But school atmosphere and the role of teacher's model cannot be replaced by any equipment or means. Therefore, the model role of a teacher with good professional ethnic is important for students in their study and life. Teachers need to improve their professional ethic in the improvement of their comprehensive quality and improve their comprehensive quality through having a good professional ethnic.

\section{WAYS TO IMPROVE THE COMPREHENSIVE QUALITY OF TEACHERS IN NORMAL COLLEGES AND UNIVERSITIES}

At present, China's education is moving in the direction of informationization. Multimedia has become a fixture in our education. Higher normal institutions are facing transformation reform. The new situation put forward new goals and new requirements on the comprehensive quality of teachers in normal colleges and universities. Based on the analysis of the questionnaire, combined with requirements of the new 
situation and status quo for teachers' comprehensive quality, the author put forward the following suggestions to improve the comprehensive quality of teachers of normal colleges and universities in Jilin:

\section{A. Teachers Should Strengthen Their Understanding}

Teacher is the beacon of the student in their life. But if this beacon is not light, it cannot beacon students but block them. Thus, teachers will produce negative impacts on students if their understandings are not good. So, teachers should strengthen their own understanding and be a beacon on the road of students. There are at least two aspects to strengthen teachers' understanding: understanding on their teaching courses and understanding on their self work. Each course has its existing reason in curriculum arrangement of school. Teachers need to recognize the importance of each subject in students' growth. Some subjects seemingly are simple, but they are important. Teachers should attaches importance to them. In addition, teachers should have a correct understanding on their duty of work. Teaching is holy and great. Teachers shouldn't take a perfunctory attitude because of any private reason, for it is irresponsible to school's arrangement and students. Teachers should strengthen their own understanding from the two aspects. In teaching, they should treat each subject and each course seriously and each student carefully. Only by strengthening teachers' understanding, can the teaching level of normal colleges and universities in Jilin be effectively improved and the comprehensive quality of teachers improved.

\section{B. Teachers Should Strengthen Learning to Improve Their Knowledge Skill and Teaching Skills}

Under the information age, first challenge of education is the basic quality of teachers. Students can find the information they need in the information age. Teachers as disseminators of knowledge shall master the latest knowledge before students. Only in this way, teachers can make students convince. On the other hand, teachers should keep up with the pace of social development in the information era, so that they are not eliminated by the trend of social development. Teachers should constantly update their knowledge and improve their knowledge skill. Therefore, under such circumstances, teachers in normal colleges and universities in Jilin should constantly study and thus improve their knowledge skill. It is the requirement of society for teachers to strengthen learning and improve their knowledge in the new era. Teachers should improve themselves to adapt to the change of the times, and update their knowledge base and improve their comprehensive quality.

Under the background of the new era, the society requires teachers to master the traditional way of teaching and study teaching constantly and create their own teaching style. In the information era, each one needs to be personalized. It is also true for teachers in normal colleges and universities. Traditional teaching can meet basic need of class, but it isn't going to help improve teaching efficiency, strengthen exchange between teachers and students and associate class with life. On this basis, teachers need to continue to study teaching, integrate class into students' daily life, add self characteristics and form own teaching style to improve the teaching efficiency of class. To continue to study teaching and form own teaching style are effective measures to improve classroom efficiency under the background of increasingly strengthened competitions among normal colleges and universities, but also are requirements of society for teachers on comprehensive quality in the new era.

\section{Teachers Should Change Their Teaching Ideas and Teaching Methods}

Modern higher education requires teachers to change their teaching methods and take students as orientation in the class. In teaching, teachers should make full play of students' enthusiasm and creativity and respect students' dominant position. Pay attention to students' ability to master knowledge and the interests of the students. Teachers respect students' dominant role in classroom, so as to strengthen the interactivity with students in teaching and improve the classroom efficiency of teaching. In addition, teachers should combine theory with practice in teaching. In modern times, society needs talents with both theory and practice ability. Society needs talents that are able to apply theory into practice and combine theory with practice, so teachers should attaches importance to the combination of theory and practice in teaching to adapt to the development of the times. In the process of teaching, it is a concrete measure for teachers to improve their self ability to combine practice with theory. It is also conducive to improving the comprehensive quality of teachers.

\section{Put Moral Education First in the Development of Education}

Every word and action of students can reflect their mind and moral education. Teachers in normal colleges and universities should not only deliver science knowledge to students but also pay attention to their moral education. It is an important indicator of the comprehensive quality of teachers in normal colleges and universities to put moral education first in the development of education. Teachers in normal colleges and universities in Jilin should pay attention to students' moral education. Teachers need to integrate moral education into daily teaching. For example, teachers can expound some virtues in teaching an article, or teach the ways to get along with people in business etiquette course. So, students can receive moral education in learning knowledge and improve their moral cultivation. Put moral education first in the development of education. It is an important test for the comprehensive quality of teachers in normal colleges and universities to perfectly integrate science knowledge, professional knowledge and moral education. Teachers in Jilin's normal colleges and universities shall do it to improve their comprehensive quality.

\section{E. Schools Should Attach Great Importance to the Examination of the Comprehensive Quality of Teachers}

School is a great environment for teachers to develop their comprehensive quality. Only schools pay attention to the examination of teachers' comprehensive quality, can it create a good environment for the development of teachers' 
comprehensive quality and it is possible to improve the comprehensive quality of teachers. It has two virtues for school to examine teachers' comprehensive quality. First, it is good for school to form a perfect evaluation system of teachers' comprehensive quality which helps change the weak points of teachers and effectively improve the comprehensive quality of teachers. Second, it can force teachers to find their shortcomings and make improvement under the limited pressure. It can create certain benign competitions among teachers, so that teachers can improve their comprehensive quality in the competitions. Under the benign circulation, the comprehensive quality of teachers in Jilin's normal colleges and universities can make a great leap. Therefore, it is helpful if schools attach importance to teachers' comprehensive quality. Leaders of Jilin's normal colleges and universities should change their management ideas, pay attention to the inspection and examination of teachers' comprehensive quality, and ensure teaching quality through strict test on teachers' comprehensive quality.

\section{F. Schools Should Give Teachers Training to Correct the Weak Points}

According to the survey, teachers in Jilin's normal colleges and universities are divided into two types: teachers with rich experience and low diploma and teachers with high diploma but lacking experience. In order to improve teachers' comprehensive quality, schools can give purposeful training aiming to the different situation of teachers. For example, schools can train teachers with low diploma but rich experience to improve their professional knowledge skill. Schools can arrange training on professional knowledge to improve these teachers' comprehensive quality. Schools can seek appropriate teachers from inside school or from other professional training institutions to give training. Teachers can improve their knowledge skill after study, and thus improve their comprehensive quality. For teachers with high diploma but lacking experience, schools can arrange training to enrich these teachers' teaching experience. Schools can arrange teachers with rich experience to make exchange. Teachers can find their shortcomings and improve themselves by exchange. Schools can arrange exchange and cooperation between schools and call for teachers to participate. So, they may have a comprehensive understanding on their own through exchange and improve their comprehensive quality.

\section{CONCLUSION}

It is an important guarantee to develop the country through science and education to improve the comprehensive quality of teachers, an important embodiment of respecting teachers, and an important symbol of modernization. With the development of the times, teachers should not only have high diploma but also develop and enrich their qualities with the change of environment. Therefore, it is a fundamental guarantee for improving teaching efficiency and an important measure to train excellent talents to improve the comprehensive quality of teachers. In order to adapt to the trend of the times, our teachers should improve their comprehensive quality constantly. Of course, it is not only a self thing to improve teachers' comprehensive quality. We believe that the comprehensive quality of teachers in normal colleges and universities can be effectively improved after the joint efforts of normal colleges and universities and teachers.

\section{REFERENCES}

[1] Huang Yongrong. Research on the Reform and Development of Norma Colleges and Universities under the Background of Teacher Education. Guangxi Normal University, Apr. 1, 2005.

[2] Niu Yafan. Theoretical Discussion on "Integrated" Art Teacher Training in Normal Colleges and Universities. Yunnan Normal University, May 28, 2006.

[3] Zhang Baoge. Discussion on Normal Problems in Local Norma Colleges and Universities in the Transformation Period of Teacher Education. Northeast Normal University, May 1, 2008. 